\title{
Indian Economy and Covid-19 Pandemic: An Analytical Review
}

\section{Parveen Kumar ${ }^{1 *}$, Feroz-Din-Sheikh ${ }^{1}$ and Pawan Kumar Sharma ${ }^{2}$}

\author{
${ }^{1}$ Sher-e-Kashmir University of Agricultural Sciences and Technology of Kashmir, Shalimar, Srinagar, India \\ ${ }^{2}$ Sher-e-Kashmir University of Agricultural Sciences and Technology of Kashmir, Jammu, JEK, India
}

*Corresponding author: pkumar6674@gmail.com

Received: $11-08-2020$

Revised: 14-11-2020

Accepted: 10-12-2020

\section{ABSTRACT}

The Covid-19 pandemic has caused some irreversible loss to human lives and to the economies all across the globe. Former Reserve Bank of India chief Raghuram Rajan described the corona virus pandemic as the 'greatest emergency since Independence'. The virus struck the country when the economy was already in a very fragile state. The growth rate in the country was low; unemployment was at an all time high. The present review paper discusses the impact of the pandemic on different sectors of Indian economy including agriculture.

Keywords: Economy, Globe, Covid-19, Pandemic, Fragile, Agriculture, Unemployment

India is an agrarian economy. Agriculture contributes about 14 per cent to the Gross Domestic Product of the country. More than fifty percent of the population still derives its livelihood from this sector. With 520 -million-workers, the Indian labour force is the world's second-largest as of 2019. The country has made remarkable progress in food grains production. From shortages we have now headed towards surpluses. Today, country is the largest producer of pulses, spices, milk, tea, cashew, jute, banana, jackfruit and many other commodities (FAO). It stands second in production of fruits and vegetables, wheat, rice, cotton and oilseeds. The country also has the largest livestock population. The 535.8 million livestock in the country constitute 31 per cent of the world's livestock population and the milk production in the country accounts for 22 per cent of the global produce. The per capita availability of milk in the country stands at 394 gram which is less as compared to 500 to 700 gram in the developed economies. The country stands at fifth position in poultry.
The COVID-19 pandemic that killed millions of peoples still continues to be a threat to the humanity. India too is still witnessing number of cases and thus devising strategies accordingly. With nearly 162 countries steadily went and some still into the lock down, the fear of an economic collapse is on the rise. The lockdown due to the pandemic that restricted every type of movement has also hit the country's economy. The present review article is an attempt to highlight the impact of COVID-19 on Indian economy.

\section{MATERIALS AND METHODS}

The present paper is an attempt to review the impact of COVID-19 pandemic and related lockdown on agriculture in India using secondary sources of information. The secondary sources include national

How to cite this article: Kumar, P., Sheikh, Din, F. and Sharma, P.K. (2020). Indian Economy and Covid-19 Pandemic: An Analytical Review. Agro Economist - An International Journal, 7(2): 75-78.

Source of Support: None; Conflict of Interest: None 
as well as international newspapers magazines, journals and TV debates of subject matter specialists, economists, planners and policy makers. The reports of various national as well as international bodies also form a part of the secondary sources. The national bodies include NITI Aayog, Indian Council of Agricultural Research (ICAR), Indian Council of Medical Research (ICMR) and others and the International bodies included World Bank, United Nations (UN) and its organizations like World Health Organization (WHO), Food and Agricultural Organization (FAO) and other organizations. The data was analyzed and compiled to be presented in a simpler language.

\section{RESULTS AND DISCUSSION}

The United Nations DESA's World Economic Forecasting has estimated best and worst case scenarios for global growth in 2020. In the best scenario with moderate declines in private consumption investment and exports and offsetting increases in government spending in the G7 countries and China, global growth would fall to 1.2 per cent in 2020. In the worst case scenario, the global output would contract by 0.9 percent instead of growing by 2.5 per cent in 2020. The report has also said that the contraction would be higher if government fails to provide income support and help boost consumer spending. The impact of Pandemic on Indian economy has been summarized as below:

\section{Growth rate}

There is clear evidence that Indian economy has been affected by the COVID-19 pandemic. The country also went into lockdown on March 25, 2020. In India, the estimated cost of a full lockdown was a whopping 26 billion U.S. dollars. Most of the loss was to occur in the June quarter. India>s quarterly GDP was estimated to a decline of over nine percent between April and June 2020. This was a decrease from a five percent growth in the beginning of 2020. In India, this situation together with a sluggish economic growth in the previous year has come at the most unfortunate time. This disruption in the country is much starker than the global financial crisis of 2008. The 2008 crisis hit the Indian financial sector but did not brought a production halt. The COVID-19 pandemic has brought a production halt too. The World Bank has forecasted the Indian economy to grow by 1.5 to 2.8 per cent in the 2020-21 fiscal starting April 1 and this is the worst since the liberalization of the 1991. The impact of the corona virus (COVID-19) lockdown in India slashed GDP growth forecasts for financial year 2021. Among the other agencies that estimated growth, Bernstein predicted a contraction of seven percent, while the Asian Development Bank foreseeing a growth of four percent. India recorded a growth of 4.2 percent in the previous fiscal year, the slowest in 11 years.

\section{Rise in Unemployment}

The unemployment in the country rose from $6.7 \%$ on 15 March to $26 \%$ on 19 April and then back down to pre-lockdown levels by mid-June (Vyas and Mahesh, 2020). During the lockdown, an estimated 14 crore (140 million) people lost employment while salaries were cut for many others. More than $45 \%$ of households across the nation have reported an income drop as compared to the previous year.

\section{Industrial Output and Tourism}

Under complete lockdown, less than a quarter of India's \$2.8 trillion economic movement was functional. Industrial output from the eight core sectors at the end of 2019 fell by $5.2 \%$ the worst in 14 years. Up to $53 \%$ of businesses in the country were projected to be significantly affected. Supply chains were under stress with the lockdown restrictions in place. A number of young startups have been impacted as funding has fallen. The tourism in the country is also hit hard by the pandemic and the lockdown. It was estimated that the loss to the tourism industry will be ₹ 15,000 crore (US\$2.1 billion) for March and April alone.

\section{Household income}

Household income in India was drastically impacted due to the corona virus (COVID-19) lockdown. There was a significant decrease in the level of income with households reporting a fall in income from about nine percent in late February to a whopping 45.7 percent in mid April. Rise in income saw a contrasting trend indicating similar results; from 31 percent in late February to 10.6 percent on April $12,2020$. 


\section{Job loss by age group}

People between the ages of 20 and 44 were most impacted by the corona virus (COVID-19) lockdown in India during April 2020 based on job loss. Over 14 percent of people between ages 40 and 44 lost their jobs in April. Naturally, this period proved most challenging for young Indians aspiring to be a part of the job market. With over 27 million young people losing jobs in April alone, massive disruptions and long-term repercussions are further expected for the economy.

\section{Impact on Agriculture}

India's nine-week-long lockdown had also impacted agriculture sector. Agricultural operations largely remained out of the purview of the lockdown restrictions, which started on 25 March 2020. As a result of this virus, first harvesting and then marketing of the produce at the farm level was under crisis across the country. Due to the disruptions in the procurement of food grains by government agencies, disruptions in the collection of harvests from the farms by private traders, a shortage of workers to harvest the rabi crop, blockades in the movement of agricultural commodities across the major highways, closure or limited operations of APMC mandis and shutdowns in the retail agricultural markets, the agriculture sector was bound too suffer. All this resulted in fall in prices of various commodities. Farmers in different states in the absence of adequate marketing support were seen throwing away their vegetables openly on roads. Wheat prices in Madhya Pradesh were reported to have fallen from ₹ 2200/ qtls to about ₹ $1600 /$ qtls by March 25, 2020. For many crops, these prices are also below the Minimum Support Prices announced. In Punjab, vegetables that were sold at $₹ 15 / \mathrm{kg}$ are reportedly being sold at a mere ₹ $1 / \mathrm{kg}$ (R. Ramakumar, 2020).

A nationwide survey conducted across 200 districts in 12 states of the country also revealed that more than half the farmer respondents who harvested their crops reported to have suffered a lower yield during the nationwide lockdown, compared to the last season of sowing the same crop. The lockdown to curb the spread of the novel corona virus disease also forced 55 per cent of the farmers to store their crops as they were unable to sell them. Over half of the farmers said the process of harvesting cost more compared to last season, primarily because of a lack of labour or machinery or higher cost of machinery. Around 20 per cent, however, said their cost of harvest was lower than last year. The survey further revealed that the situation was not much different for vegetables and other crops in non-wheat growing states. In West Bengal, only 19 per cent of the 81 per cent farmers who harvested vegetables were able to sell their produce. Vegetable farmers across the surveyed states, in fact, reported the highest amount of wastage. The farmers from Punjab were often seen throwing their vegetables open in the road as they could not get a fair price of their produce. Out of total 77 per cent of livestock farmers in the survey, 63 per cent reported a decline in milk production largely due to the restriction that farming community was unable to procure feed and fodder income, with an average decline of 36 per cent compared to January and February.

The country has responded to the pandemic by announcing a host of measures that included financial packages. To protect vulnerable peoples including smallholder farmers, agricultural labourers and migrant workers, the government announced a package of rupees 1.76 lakh crore under the name of Primeminister Garib Kalyan Yojana. Under this package besides other, a sum of rupees two thousand under Primeminister Kisan Samman Nidhi was credited into the account of the farmers. Another stimulus package worth rupees 20 lakh crore was announced by the Primeminister under the 'Aatma Nirbhar Bharat' Special Package.

The corona crisis came as a blessing for the farming community and the govt. of India came up with three major ordinances which many believe is a watershed moment in Indian agriculture. On $5^{\text {th }}$ June 2020, the government of India headed by Sh. Narendra Modi promulgated three major ordinances which now have been passed by the parliament and are now laws. The Farming Produce Trade and Commerce (Promotion and Facilitation) law gives the farming community the freedom of choice of sale and purchase of their produce of both interstate as well as intrastate. The Amendment to Essential Commodities Act makes it possible for producers to store their produce and sell it when the prices are remunerative. Now, the central government may regulate the supply of certain food items including 
cereals, pulses, potato, onions, edible oilseeds, and oils, only under extraordinary circumstances. These include: (i) war, (ii) famine, (iii) extraordinary price rise and (iv) natural calamity of grave nature. The Farmers' (Empowerment and Protection) Agreement on Price Assurance and Farm Services Act has made contract farming more farmer friendly and much to the advantage of farming community. To put it simply, this ordinance provides a legal basis to the existing practice of contract farming in India's agriculture and allied sectors. Farmers may enter into a written agreement which can specify terms and conditions of quality, grade, time of supply price and the extension services etc. The agreement could be for a period of 1 to 5 years.

\section{CONCLUSION}

Every challenge gives us an opportunity. Consequent to the lockdown imposed due to pandemic, the country witnessed many reform measures. With a potent strategy to uplift the country's economy, it is sure that positive results will be seen in the near future. The country is witnessing a demographic dividend too. India has more than 50 per cent of its population below the age of twenty five (Lakshmanan, R. 2021). If we are able to channelize the energy of youth in the positive direction, we can achieve many milestones. Keeping this in mind, the government has also started many Entrepreneurial Development Programmes Startup India, Standup India, incubators, various skill development programmes will lead to empowerment of youths; when youths will be job providers instead of job seekers. Under the Atal Innovation Mission, Atal Tinkering Labs (ATLs) set up across the country are helping school students to find solutions to problems facing their communities. 68 Atal Incubation Centers support more than 1500 startups in the country and over 6000 ATLs have been set up to promote a culture of innovation and entrepreneurship in the country (Rao, K. 2021). As for as agriculture is concerned, the three laws will together go a long way in unshackling the entire agriculture value chain from production to post harvest storage and processing. For the marketing of their produce, Agricultural Produce Marketing Committees are now not the only option for farmers. The new law provides the farming community the freedom to choose from a new set of buyers to get more remunerative prices. These reforms are also likely to bring in more investments in the country's economy. Let us hope that with all these, the present government's endaveour to make India a vibrant economy with thrust on self reliance and sustainability is achieved.

\section{REFERENCES}

Economic Times. 2020. A Bigger Hit on the Economy?. The Economic Times (ET Graphics). 21 May 2020, accessed on June $28,2020$.

FAO. 2020. FAO urges at G20 meeting protection of food supply chains amid COVID-19 threat, cited at www.fao. org > news > story > item > icode, accessed on May 18, 2020.

GoI. 2020. Building an Atmanirbhar Bharat, cited at www.india gov.in>spotlight>building-atmanirbhar-bharat, accessed on June 22, 2020.

GoI. 2020. Prime Minister Garib Kalyan Yojana, cited at pib. gov.in>PressReleasePag. accessed on June 20, 2020.

Lakshamanan, R. 2021. Rural India-The Periphery of Development. Kurukshetra, 69(4).

Rao, R.K. 2021. Empowering youth: towards rebuilding rural India. Kurukshetra, 69(4): 5-9.

Shagun, K. 2020. COVID-19: 60\% farmers suffered yield loss on their harvest, cited at www.downtoearth.org. in>news>agriculture $>$ covid, accessed on June 27, 2020

The Times of India. 2020. India Stimulus Package: Government's economic package only $1 \%$ of GDP, say analysts. The Times of India (20 May 2020).

UNDESA. 2020. Global economy could shrink by almost $1 \%$ in 2020 due to COVID-19 pandemic: United Nations. United Nation Department of Economic and Social Affairs (UNDESA), cited at https://economictimes. indiatimes.com/news/international/business/globaleconomy-could-shrink-by-almost-1-in-2020-due-to-covid19-pandemic-united-nations/articleshow/7494, accessed on May 17, 2020

Vyas, M. 2020. Livelihood at stake for millions as employment crisis, cited at www.business-standard.com $>$ Economy $\mathcal{E}$ Policy. Accessed on June 28, 2020. 